EISSN: 2706 -7947 ISSN: 2077- 4613

DOI: 10.36632/mejas/2021.11.2.42

Journal homepage: www.curresweb.com

Pages: 514-530

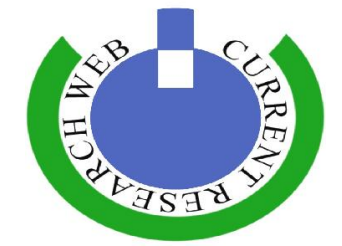

\title{
Preparation and evaluation high quality free gluten flat bread II: Effect of using improvers on freshness, texture profile analysis and sensory evaluation
}

\author{
Manal H. Abd-Elkader ${ }^{1}$, Nahed S. Yousef ${ }^{2}$ and Samah A.T. Abu El-maaty ${ }^{2}$ \\ ${ }^{1}$ Bread and Pastries Research Dept., Food Technology Research Institute, Agricultural Research \\ Center, Giza, Egypt. \\ ${ }^{2}$ Food Science and Technology Dept., Faculty of Home Economics, Al-Azhar University, Egypt. \\ Received: 25 April $2021 \quad$ Accepted: 30 May $2021 \quad$ Published: 10 June 2021
}

\begin{abstract}
From a commercial perspective, there is a need for the development of gluten-free bread with texture and flavor properties similar to conventional wheat flour bread. Appearance, texture, taste, and odor in free gluten bread are poor as compared to wheat bread. Free gluten bread staled in few hours and has low freshness than wheat bread. This research tried to produce high-quality free gluten bread in sensorial and texture properties as well as extend freshness. Six different sources of gluten-free flours, rice flour $(\mathrm{R})$, corn flour $(\mathrm{C})$, millet seed powder $(\mathrm{M})$, flax seed powder $(\mathrm{F})$, rice bran $(\mathrm{B})$, and potato powder $(\mathrm{P})$ were selected. Five improvers as okra, guar gum, and xanthan gum, whey protein, and white egg were examined to obtain different combinations and compositions of free gluten flatbread. The moisture content, water activity, texture profile analysis, freshness, and sensory properties of glutenfree flatbread were determined. The obtained results observed that moisture content and water activity increased by increasing improver levels in all formulas. The okra improver recorded the highest moisture contents at zero time and the lowest decreasing rate after $48 \mathrm{~h}$ of storage. The freshness of all gluten-free bread samples was increased by increasing improver's levels at zero time. The highest water retention capacity was in okra followed by xanthan and guar gum mixture improvers at zero time and after $48 \mathrm{~h}$ in all bread samples. Hardness, gumminess, and chewiness decrease by increased improvers levels and increased gradually by storage time. Using okra and a mixture of xanthan \& guar gum improvers in different levels enhanced all parameters of sensory gluten-free flatbread. Higher overall acceptability values were in MRP, FRP, and BCRP with $7 \mathrm{~g}$ okra $(99.17,96.33$, and 94.67, respectively). There is no raw material, additives, or ingredients that can completely substitute gluten, but the combination of different raw materials, ingredients, and proper production technologies could promote the production of the gluten-free product of good quality. The results showed that adding okra at different levels led to increase in water activity, freshness, water retention capacity and enhanced sensory attribute of the gluten free flatbread compared to other used improvers.
\end{abstract}

Keywords: Free-gluten, improvers, staling, texture profile, sensory analysis

\section{Introduction}

Several approaches have been applied to understand and improve gluten-free bread elaboration including the use of novel alternative flours, functional ingredients, processing aids, additives, innovative techniques, and their combinations (Wang et al., 2017). The use of hydrocolloids in glutenfree breads is a strategy to improve their quality and obtain products with acceptable structural and textural properties. Hydration level optimization is important to maximize the hydrocolloids effects on dough and bread quality. Psyllium had similar behavior to xanthan with respect to specific volume and weight loss. Breads manufactured with maize starch and hydroxypropyl methylcellulose (HPMC) had greater hydration level and low hardness due to their great specific volume. The hydration decreased of

Corresponding Author: Manal H. Abd-Elkader, Bread and Pastries Research Dept., Food Technology Research Institute, Agricultural Research Center, Giza, Egypt.

E-mail: haggag_eg@yahoo.com 
breads made with rice flour caused harder bread in similar specific volume with HPMC than the use of psyllium or xanthan.

Breads made with HPMC presented higher specific volume than the other hydrocolloids; however combinations among these hydrocolloids could be evaluated to improve gluten-free breads quality (Belorio and Gómez, 2020).

Hydrocolloids are often used as a thickening agent, binding water and increasing dough viscosity, for better volume, texture, and final quality of bread (Mir et al., 2016). HPMC and xanthan gum are the most widely used hydrocolloids in gluten-free formulation due to their capacity to improve the quality of the products. Other hydrocolloids such as guar gum, $\mathrm{CMC}$, locus bean gum and agarose are also used in gluten-free dough's, (Hager and Arendt, 2013). Previous research focused on molecular structure, physicochemical properties, and uses in food products of the whole class of hydrocolloids as bread improvers (Kohajdova and Karovicova, 2009).

Mandala and Sotirakoglou (2005) suggested that the use of xanthan gum and guar-gum in fresh or microwave-heated bread after frozen storage was able to retain water in the crumb and consequently, moisture migration to the crust, thus resulting in the crust to reduce deformation and decrease samples firmness. Xanthan gum used at low concentrations, on the other hand, improved the crumb viscoelastic properties on defrosted and microwave-heated samples, probably by delaying the deteriorating effects and avoiding the development of a spongy structure during frozen storage. Moreover, xanthan gum has been addressed to retard amylose retrogradation, due to reduced amylose-amylose interactions.

Loss of important sensory parameters of bread, like flavor and texture was occurred as a result of staling and it is a consequence of a group of several physical-chemical changes occurring during bread storage that lead mainly to an increase of crumb firmness and loss of freshness (Kulp and Ponte, 1981 and Gray and BeMiller, 2003).

$\mathrm{Wu}$ et al., (2009) found that addition of potato paste at levels 5\% to $20 \%$ decreased staling in first day of stored samples with respect to control breads and they associated with the differences in waterbinding capacities of potato paste and with interaction with starch, thus affecting starch retrogradation. Hydrocolloids have been widely investigated as additives and improvers. The most noteworthy applications are to improve food texture and viscoelasticity; act as water binders; extend the overall quality of products during storage; slow down starch retrogradation and act as a gluten substitute. Usually, they are added to dough as a structuring agent, with the aim of imitating gluten network properties (Arendt et al., 2008; Arendt and Dal Bello, 2008; Duodu and Taylor, 2012 and Matos and Rosell, 2015). Hydrocolloids are able to give stability to products that undergo successive freeze-thaw cycles. Moreover, they are a good fat substitute in many products, especially as, at concentrations below $1 \%$, they have been found to have a significant influence on dough rheology and bread characteristics (Arendt et al., 2008 and Arendt and Dal Bello, 2008). Carboxymethyl cellulose (CMC), guar gum, sodium alginate, $\kappa$-carrageenan, xanthan gum, and hydroxypropyl methylcellulose (HPMC) are effective improvers (Matos and Rosell, 2015 and Ren et al., 2020). These agents are extensively used to modify starch gelatinization, and improve pasting properties and gelling. Moreover, they have been found to improve dough development and gas retention capacity, through an increase in viscosity, with a subsequent increase in loaf volume. In particular, Arendt et al., (2008) highlighted that; hydrocolloid addition can increase elasticity and deformation resistance.

This study aimed to produce high quality gluten free bread with some improver as okra, xanthan gum \& guar gum, whey protein and white egg. This improvers added to gluten free composite flour to mimic the viscoelastic properties of gluten and improve structure, sensory as well as prolong freshness.

\section{Materials and Methods}

\subsection{Materials}

\subsubsection{The raw materials of gluten-free flour:}

White rice flour, corn flour and potato powder were purchased from Tiba Food Industries Company, at Burj Al Arab Alexandria, Egypt. Stabilized rice bran obtained from Agricultural Engineering Research institute. While, Pearl millet and flax seeds powder were obtained from Forage Crops Research Department, Field Crops Institute, Agriculture Research Center, Giza, Egypt.

Fresh okra was obtained from the local market of Mit Ghamr, El-Mansoura City, El Dakahlia Governorate, Egypt. 
Xanthan and guar gums were obtained from Free Gluten Center, Food Technology Research Institute, Agriculture Research Center, Giza, Egypt. While, whey protein powder and white egg powder were purchased from the whole sale market of Bab El bahr, Cairo, Egypt.

\subsection{Methods}

Preparation of okra, pearl millet and flax seeds powder were described in the part I of this work. Formula of dough samples of gluten-free flat bread was presented in Table 1 and bread-making process was performed according to the procedures described in the Part I of this work.

Table 1: The formula (g) of gluten-free flat bread samples

\begin{tabular}{ccccccc}
\hline Sample & $\begin{array}{c}\text { Corn } \\
\text { flour }\end{array}$ & $\begin{array}{c}\text { Rice } \\
\text { flour }\end{array}$ & $\begin{array}{c}\text { Potato } \\
\text { powder }\end{array}$ & $\begin{array}{c}\text { Millet } \\
\text { powder }\end{array}$ & $\begin{array}{c}\text { Flax seeds } \\
\text { powder }\end{array}$ & $\begin{array}{c}\text { Rice } \\
\text { bran }\end{array}$ \\
\hline MRP & - & 75 & 50 & 25 & - & - \\
FRP & - & 75 & 50 & - & 25 & - \\
BCRP & 30 & 50 & 50 & - & - & 20 \\
\hline
\end{tabular}

\subsection{Analytical methods}

\subsubsection{Determination of moisture content and water activity $\left(a_{w}\right)$ of gluten-free flat bread}

The moisture content was determined according to AOAC (2010). The water activity $\left(a_{\mathrm{w}}\right)$ was measured with a Rotronic (model Hygrolab3 made in Switzerland). (Piga et al., 2005).

\subsubsection{Determination the freshness rate of gluten-free flat bread}

Alkaline water retention capacity of breads was measured at zero time, 24 and $48 \mathrm{~h}$ of bread storage at room temperature according to the method of Kitterman and Rubenthaler (1971).

\subsubsection{Texture profile analysis of gluten-free flat bread}

A texture analyzer (BROOKFIELD CT3 TEXTURE ANALYZER Operating Instructions Manual No., M08-372-C0113, Stable Micro Systems, USA) was used to measure the texture profile of flat bread (Bourne et al., 2003).

\subsubsection{Sensory evaluations of high fiber gluten- free flat bread}

Ten panelists of Food Technology Institute organolyptic evaluated gluten-free flat bread samples for general appearance (20), crust color (15), odor (10), taste (20), texture (10), separation of layers (15), roundness (10) and overall acceptability (100). The evaluation was carried out according to the method of Zahran et al., (2005).

\subsection{Statistical Analysis}

The data were analyzed according to Steel and Torrie (1980). Analyses were performed with SPSS program (SPSS Inc., Chicgo, IL. USA) the data were analyzed by one-way analysis of variance (ANOVA). Means separation was performed by Duncan's multiple range tests. Differences at $\mathrm{p} \leq 0.05$ were considered as significant (Armitage et al., 1987).

\section{Results}

\subsection{Effect of tested improvers on the moisture content of gluten-free flat bread samples.}

Effect of tested improvers (okra, xanthan \& guar mixture, white egg and whey protein) on moisture content of gluten-free flat bread samples was determined at zero time, after 24 and 48 hours and the results are shown in Table (2). From the results, it could be noticed that there were significant differences in moisture content between all gluten-free flat bread samples with different improvers.

Moisture content was significantly increased by increasing improver levels in all formulas. The highest moisture content was found by using 7\% okra improvers in MRP and BCRP at zero time by 41.78 and $41.98 \%$, respectively. Rosell et al., (2001) similarly reported an increase of water activity as well of moisture retention due to the higher water holding capacity of the hydrocolloids.

The moisture content was decreased by increasing storage period (after $24 \mathrm{~h}$ and $48 \mathrm{~h}$ ). The decreasing rate of moisture at the end of storage period reached to $8.45 \%, 3.65 \%$ and $5.62 \%$ in MRP, 
FRP and BCRP with $7 \mathrm{~g}$ okra improvers, respectively. As well as, the highest percentage of white egg $4 \mathrm{~g}$ had decreased in moisture content by $13.48,11.18$ and $12.68 \%$ for MRP, FRP and BCRP, respectively at the end of storage period. These results may be due to the chemical composition of okra and high content of fiber (Table 2 in part I) and mucilage. Deogade et al., (2012) reported that mucilage is a plant hydrocolloid which is a polymer of a monosaccharide or mixed monosaccharide.

Table 2: Moisture content of gluten-free flat bread samples with different levels of improvers during storage period at room temperature

\begin{tabular}{|c|c|c|c|c|c|c|c|c|c|}
\hline \multirow{3}{*}{$\begin{array}{c}\text { Improver } \\
\text { g/150g } \\
\text { formula }\end{array}$} & \multirow{2}{*}{\multicolumn{3}{|c|}{$\begin{array}{c}\text { MRP } \\
\text { Storage period(h) }\end{array}$}} & \multicolumn{3}{|c|}{ FRP } & \multicolumn{3}{|c|}{$\overline{\text { BCRP }}$} \\
\hline & & & & \multicolumn{3}{|c|}{ Storage period(h) } & \multicolumn{3}{|c|}{ Storage period(h) } \\
\hline & $\mathbf{0}$ & 24 & 48 & $\mathbf{0}$ & 24 & 48 & $\mathbf{0}$ & 24 & 48 \\
\hline \multicolumn{10}{|c|}{ Okra } \\
\hline 3 & $39.46^{\mathrm{de}}$ & $38.23^{\mathrm{cd}}$ & $37.41^{\mathrm{b}}$ & $38.44^{\mathrm{e}}$ & $37.79^{c}$ & $36.59^{\mathrm{c}}$ & $40.41^{\mathrm{cd}}$ & $39.28^{c}$ & $38.75^{\mathrm{b}}$ \\
\hline 5 & $40.71^{b}$ & $39.12^{\mathrm{b}}$ & $37.78^{\mathrm{ab}}$ & $39.55^{\mathrm{d}}$ & $38.57^{\mathrm{b}}$ & $37.69^{b}$ & $41.23^{b}$ & $40.05^{b}$ & $38.62^{b}$ \\
\hline 7 & $41.78^{\mathrm{a}}$ & $40.36^{\mathrm{a}}$ & $38.25^{\mathrm{a}}$ & $40.22^{b c}$ & $39.50^{\mathrm{a}}$ & $38.75^{\mathrm{a}}$ & $41.98^{\mathrm{a}}$ & $40.66^{\mathrm{a}}$ & $39.62^{a}$ \\
\hline \multicolumn{10}{|c|}{ Xanthan \& guar } \\
\hline 0.8 & $38.98^{\mathrm{e}}$ & $37.14^{\mathrm{ef}}$ & $34.08^{\mathrm{e}}$ & $39.59^{\mathrm{d}}$ & $37.13^{\mathrm{d}}$ & $34.85^{\mathrm{d}}$ & $39.96^{\mathrm{de}}$ & $37.67^{\mathrm{e}}$ & $35.82^{\mathrm{de}}$ \\
\hline 1.2 & $39.77^{\mathrm{cd}}$ & $38.63^{\mathrm{bc}}$ & $35.88^{\mathrm{d}}$ & $40.70^{\mathrm{b}}$ & $38.05^{\mathrm{c}}$ & $36.60^{\mathrm{c}}$ & $40.69^{c}$ & $38.64^{\mathrm{d}}$ & $36.25^{\mathrm{d}}$ \\
\hline 1.6 & $40.34^{\mathrm{bc}}$ & $38.84^{\mathrm{bc}}$ & $36.89^{\mathrm{c}}$ & $41.66^{\mathrm{a}}$ & $39.04^{\mathrm{ab}}$ & $37.92^{b}$ & $41.78^{\mathrm{a}}$ & $39.64^{\mathrm{bc}}$ & $37.99^{c}$ \\
\hline \multicolumn{10}{|c|}{ White egg } \\
\hline 2 & $34.40^{\mathrm{i}}$ & $31.76^{\mathrm{j}}$ & $29.66^{\mathrm{i}}$ & $32.07^{\mathrm{h}}$ & $29.16^{\mathrm{h}}$ & $27.34^{\mathrm{h}}$ & $36.04^{\mathrm{h}}$ & $33.82^{\mathrm{i}}$ & $31.94^{\mathrm{h}}$ \\
\hline 3 & $35.20^{\mathrm{h}}$ & $32.75^{\mathrm{i}}$ & $30.77^{\mathrm{h}}$ & $35.78^{\mathrm{g}}$ & $32.87^{\mathrm{g}}$ & $30.37^{\mathrm{g}}$ & $37.28^{\mathrm{g}}$ & $33.84^{\mathrm{i}}$ & $32.18^{\mathrm{h}}$ \\
\hline 4 & $36.80^{\mathrm{g}}$ & $34.11^{\mathrm{h}}$ & $31.84^{\mathrm{g}}$ & $37.02^{\mathrm{f}}$ & $35.41^{\mathrm{e}}$ & $32.88^{\mathrm{f}}$ & $38.86^{\mathrm{f}}$ & $35.23^{\mathrm{g}}$ & $33.93^{\mathrm{f}}$ \\
\hline \multicolumn{10}{|c|}{ Whey protein } \\
\hline 3 & $37.87^{\mathrm{f}}$ & $34.97^{\mathrm{g}}$ & $33.52^{\mathrm{f}}$ & $37.14^{\mathrm{f}}$ & $33.83^{\mathrm{f}}$ & $32.50^{\mathrm{f}}$ & $38.47^{\mathrm{f}}$ & $34.60^{\mathrm{h}}$ & $32.79^{\mathrm{g}}$ \\
\hline 5 & $38.05^{\mathrm{f}}$ & $36.57^{\mathrm{f}}$ & $34.37^{\mathrm{e}}$ & $38.53^{\mathrm{e}}$ & $35.83^{\mathrm{e}}$ & $33.91^{\mathrm{f}}$ & $39.79^{\mathrm{e}}$ & $36.6^{\mathrm{f}}$ & $33.80^{\mathrm{f}}$ \\
\hline 7 & $39.77^{\mathrm{cd}}$ & $37.70^{\text {de }}$ & $35.94^{\mathrm{d}}$ & $39.83^{\text {cd }}$ & $36.77^{\mathrm{d}}$ & $34.19^{\mathrm{e}}$ & $40.81^{\mathrm{bc}}$ & $37.74^{\mathrm{e}}$ & $35.57^{\mathrm{e}}$ \\
\hline
\end{tabular}

In a column, means having the same superscript letters are not significantly different at $5 \%$ level.

$\mathrm{MRP}=25 \mathrm{~g}$ millet $+75 \mathrm{~g}$ rice $+50 \mathrm{~g}$ potato; $\mathrm{FRP}=25 \mathrm{~g}$ flax seeds $+75 \mathrm{~g}$ rice $+50 \mathrm{~g}$ potato; $\mathrm{BCRP}=20 \mathrm{~g}$ rice bran $+30 \mathrm{~g}$ corn $+50 \mathrm{~g}$ rice $+50 \mathrm{~g}$ potato.

\subsection{Effect of using improvers on water activity of gluten-free flat bread samples.}

Water activity was increased significantly in all tested samples by increasing the improver's levels and decreased gradually by increasing the storage period (Table 3 ). The decrease in $\mathrm{a}_{\mathrm{w}}$ values during storage might be due to the decrease in moisture content. Water content is critical, as it influences loaf quality, texture, taste, smell, volume, flavor, and mouth-feel, and various studies have highlighted the influence of water mobility and distribution on dough rheology and baking performance (Ren et al., 2020). Benkadri et al., (2021) found that the xanthan gum effect was found to be more pronounced than locust bean gum. Interaction terms showed a significant positive effect on the specific volume of the biscuits and a negative effect on the water activity.

\subsection{Effect of using improvers on gluten-free flat bread staling during storage period at room temperature}

Freshly baked flatbreads are soft and elastic. When kept at room temperature they stale within few hours and become hard and tough (Shalini and Laxmi, 2007). Staling rate (alkaline water retention capacity) of gluten-free flatbread samples was determined at zero time, after 24 and 48 hours as shown in Table 4. The alkaline water retention capacity was increased by increasing improver's levels at zero time for all gluten-free bread samples. The staling rate decrease by increasing improvers levels. The alkaline water retention capacity values were decreased gradually by increasing storage time. Okra showed the highest water retention capacity compared with other improvers for all bread samples followed by xanthan and guar gum mixture improver at zero time and after $48 \mathrm{~h}$. Hydrocolloids are added to bakery products to an extent their shelf-life by keeping the moisture content and retarding the staling (Gray and BeMiller, 2003 and Barcenas et al., 2004).

Alkaline water retention capacity in Table (4) was $306.50,309.73$, and $316.82 \%$ at zero time for MRP, FRP, and BCRP gluten-free bread samples with 3\% okra, respectively. However, it was increased by 
Table 3: Water activity of gluten-free flat bread with different levels of improvers during storage period at room temperature

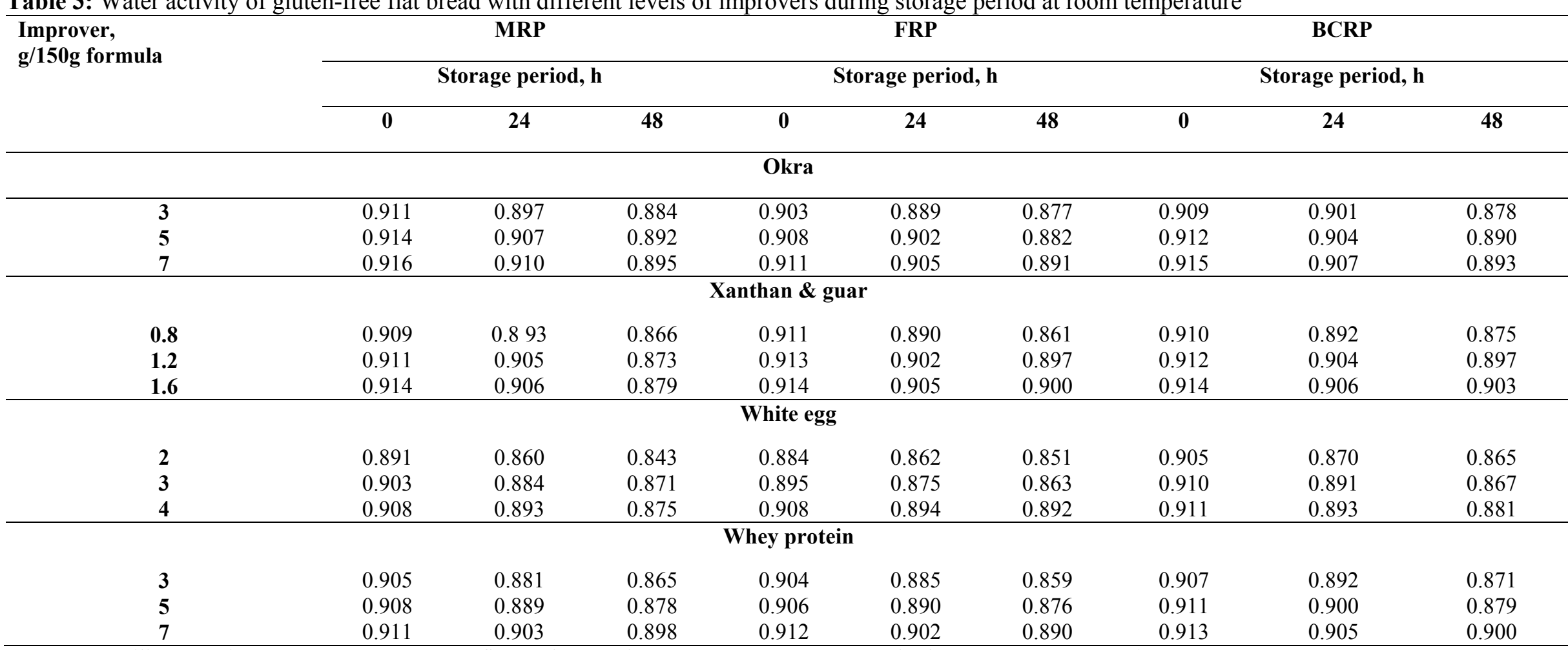

$\mathrm{MRP}=25 \mathrm{~g}$ millet $+75 \mathrm{~g}$ rice $+50 \mathrm{~g}$ potato; $\mathrm{FRP}=25 \mathrm{~g}$ flax seeds $+75 \mathrm{~g}$ rice $+50 \mathrm{~g}$ potato $\mathrm{BCRP}=20 \mathrm{~g}$ rice bran $+30 \mathrm{~g}$ corn $+50 \mathrm{~g}$ rice $+50 \mathrm{~g}$ potato 
Table 4: Staling of gluten-free flat bread samples with different levels of improvers during storage period at room temperature

\begin{tabular}{|c|c|c|c|c|c|c|c|c|c|c|c|c|}
\hline \multirow{3}{*}{$\begin{array}{c}\text { Improver } \\
\text { (g/150g } \\
\text { formula) }\end{array}$} & \multicolumn{11}{|c|}{ Alkaline water retention capacity, \% } & \multirow{3}{*}{$\begin{array}{l}\text { Staling } \\
\quad \%\end{array}$} \\
\hline & \multicolumn{3}{|c|}{ MRP } & \multirow{2}{*}{$\begin{array}{c}\text { Staling } \\
(\%)\end{array}$} & \multicolumn{3}{|c|}{ FRP } & \multirow{2}{*}{$\begin{array}{c}\text { Staling } \\
\%\end{array}$} & \multicolumn{3}{|c|}{ BRCP } & \\
\hline & $\begin{array}{l}\text { Zero } \\
\text { time }\end{array}$ & $\begin{array}{c}\text { After } 24 \\
\text { hours }\end{array}$ & $\begin{array}{c}\text { After } 48 \\
\text { hours }\end{array}$ & & $\begin{array}{c}\text { Zero } \\
\text { time }\end{array}$ & $\begin{array}{c}\text { After } 24 \\
\text { hours }\end{array}$ & $\begin{array}{c}\text { After } 48 \\
\text { hours }\end{array}$ & & $\begin{array}{l}\text { Zero } \\
\text { time }\end{array}$ & $\begin{array}{c}\text { After } 24 \\
\text { hours }\end{array}$ & $\begin{array}{c}\text { After } 48 \\
\text { hours }\end{array}$ & \\
\hline \multicolumn{13}{|c|}{ Okra } \\
\hline 3 & $306.50^{\mathrm{d}}$ & $247.20^{\mathrm{f}}$ & $234.60^{\mathrm{e}}$ & 23.46 & $309.73^{\mathrm{e}}$ & $263.97^{\mathrm{c}}$ & $245.64^{\mathrm{e}}$ & 20.69 & $316.82^{\mathrm{e}}$ & $269.40^{\mathrm{e}}$ & $236.56^{\mathrm{h}}$ & 25.33 \\
\hline 5 & $314.76^{c}$ & $291.63^{b}$ & $272.59^{\mathrm{b}}$ & 13.39 & $320.69^{b}$ & $276.79^{\mathrm{b}}$ & $276.18^{\mathrm{b}}$ & 13.89 & $328.50^{\mathrm{c}}$ & $273.63^{\mathrm{d}}$ & $255.65^{\mathrm{d}}$ & 22.18 \\
\hline 7 & $328.70^{\mathrm{a}}$ & $303.40^{\mathrm{a}}$ & $286.53^{\mathrm{a}}$ & 12.83 & $333.48^{\mathrm{a}}$ & $299.30^{\mathrm{a}}$ & $283.64^{\mathrm{a}}$ & 14.95 & $339.20^{\mathrm{a}}$ & $300.42^{\mathrm{a}}$ & $270.73^{\mathrm{a}}$ & 20.19 \\
\hline \multicolumn{13}{|c|}{ Xanthan \& guar gum } \\
\hline 0.8 & $298.45^{\mathrm{f}}$ & $230.53^{\mathrm{h}}$ & $215.30^{\mathrm{i}}$ & 27.86 & $301.65^{\mathrm{f}}$ & $260.55^{\mathrm{d}}$ & $222.62^{\mathrm{i}}$ & 26.19 & $313.53^{\mathrm{f}}$ & $273.77^{\mathrm{h}}$ & $207.86^{\mathrm{i}}$ & 33.70 \\
\hline 1.2 & $303.46^{\mathrm{e}}$ & $247.35^{\mathrm{f}}$ & $229.52^{\mathrm{g}}$ & 24.37 & $314.64^{\mathrm{d}}$ & $275.51^{\mathrm{b}}$ & $231.86^{\mathrm{g}}$ & 26.31 & $322.25^{\mathrm{d}}$ & $286.28^{\mathrm{c}}$ & $238.30^{\mathrm{g}}$ & 26.05 \\
\hline 1.6 & $318.75^{b}$ & $280.31^{\mathrm{c}}$ & $236.58^{\mathrm{d}}$ & 25.78 & $316.83^{c}$ & $299.67^{\mathrm{a}}$ & $249.95^{\mathrm{d}}$ & 21.11 & $336.75^{\mathrm{b}}$ & $293.52^{\mathrm{b}}$ & $264.63^{\mathrm{b}}$ & 21.42 \\
\hline \multicolumn{13}{|c|}{ White egg } \\
\hline 2 & $254.84^{\mathrm{j}}$ & $223.74^{\mathrm{i}}$ & $203.61^{\mathrm{k}}$ & 20.10 & $277.35^{\mathrm{j}}$ & $240.56^{\mathrm{g}}$ & $215.78^{j}$ & 22.19 & $276.35^{\mathrm{j}}$ & $247.79^{\mathrm{g}}$ & $209.71^{\mathrm{k}}$ & 24.11 \\
\hline 3 & $267.50^{\mathrm{i}}$ & $242.74^{\mathrm{g}}$ & $219.63^{\mathrm{h}}$ & 17.89 & $286.85^{\mathrm{i}}$ & $254.82^{\mathrm{e}}$ & $227.35^{\mathrm{h}}$ & 20.74 & $285.30^{\mathrm{i}}$ & $254.34^{\mathrm{f}}$ & $223.30^{\mathrm{i}}$ & 21.73 \\
\hline 4 & $303.89^{\mathrm{e}}$ & $264.51^{\mathrm{e}}$ & $248.66^{c}$ & 18.17 & $295.68^{\mathrm{h}}$ & $250.91^{\mathrm{f}}$ & $238.20^{\mathrm{f}}$ & 19.44 & $293.50^{\mathrm{h}}$ & $269.84^{\mathrm{e}}$ & $241.35^{\mathrm{f}}$ & 17.77 \\
\hline \multicolumn{13}{|c|}{ Whey protein } \\
\hline 3 & $275.53^{\mathrm{h}}$ & $229.55^{\mathrm{h}}$ & $208.59^{j}$ & 24.29 & $263.46^{\mathrm{k}}$ & $233.55^{\mathrm{i}}$ & $209.73^{\mathrm{k}}$ & 20.39 & $308.65^{\mathrm{g}}$ & $238.50^{\mathrm{h}}$ & $219.03^{j}$ & 29.08 \\
\hline 5 & $290.54^{\mathrm{g}}$ & $241.57^{\mathrm{g}}$ & $218.75^{\mathrm{h}}$ & 24.70 & $298.45^{\mathrm{g}}$ & $254.22^{\mathrm{h}}$ & $239.28^{\mathrm{f}}$ & 20.15 & $313.04^{\mathrm{f}}$ & $268.50^{\mathrm{e}}$ & $243.83^{\mathrm{e}}$ & 22.11 \\
\hline 7 & $302.40^{\mathrm{e}}$ & $267.43^{\mathrm{d}}$ & $232.52^{\mathrm{f}}$ & 23.11 & $313.68^{d}$ & $264.67^{\mathrm{c}}$ & $258.49^{c}$ & 17.59 & $321.51^{\mathrm{d}}$ & $285.94^{\mathrm{c}}$ & $260.80^{c}$ & 18.88 \\
\hline
\end{tabular}

In a column, means having the same superscript letters are not significantly different at $5 \%$ level.

$\mathrm{FRP}=25 \mathrm{~g}$ flax seeds $+75 \mathrm{~g}$ rice $+50 \mathrm{~g}$ potato; $\mathrm{MRP}=25 \mathrm{~g}$ millet $+75 \mathrm{~g}$ rice $+50 \mathrm{~g}$ potato; $\mathrm{BCRP}=20 \mathrm{~g}$ rice bran $+30 \mathrm{~g}$ corn $+50 \mathrm{~g}$ rice $+50 \mathrm{~g}$ potato 
increasing okra levels to $7 \%$ at zero time and reached $328.70,333.48$, and $339.2 \%$, respectively for the same samples. After $48 \mathrm{~h}$, at room temperature, alkaline water retention capacity decreased to 286.53 , 283.64, and $270.73 \%$ for MRP, FRP, and BCRP with 7\% okra, respectively. Although gluten-free bread FRP, MRP, and BCRP with white egg and whey protein improver showed the lowest alkaline water retention capacity during storage period at room temperature, the white egg had the lowest staling rate after 48 of the storage period in most gluten-free bread samples (Table 4). Moor et al., (2006) stated that hydrocolloids such as pectin, xanthan gum, and guar gum mixture and improvers are added naturally gluten-free flours to mimic the viscoelastic properties of gluten and to improve the structure, sensory attributes, and shelf-life of products.

\subsection{Effect of using improvers on texture profile analysis of gluten-free flat bread during storage period at room temperature}

Texture defined as the sensory manifestation of food structure and the way in which this structure reacts to the forces applied, represents the junction of all the mechanical, geometric and superficial attributes of a product, sensed through mechanical, tactile, visual and hearing receptors (Szczesniak et al., 1963).

Tables from 5 to 7 illustrated the effect of the used improvers on texture profile analysis of formulas gluten-free flat bread samples during storage period at room temperature.

Hardness is an important factor in bakery products science it is strongly correlated with consumer's perception of bread freshness (Onyango et al., 2011).

The hardness in zero time of flatbread gluten-free samples MRP, FRP, and BCRP was high in the low levels of improvers and decreased gradually by increasing the improvers levels (Tables 5-7). Hardness in all samples with different improvers increased after 24 and 48 hours of storage. After 48 hours, the maximum hardness has appeared in MRP flatbread with $3 \mathrm{~g}$ okra improver $(44.85 \mathrm{~N})$ and 2 $\mathrm{g}$ white egg improver $(44.36 \mathrm{~N})$ followed by $3 \mathrm{~g}$ whey protein improver $(38.90 \mathrm{~N})$. While maximum hardness after $48 \mathrm{~h}$ was found in FRP flatbread with $2 \mathrm{~g}$ white egg $(43.45 \mathrm{~N})$ and $3 \mathrm{~g}$ okra (39.50) followed by $0.8 \mathrm{~g}$ xanthan $\&$ guar gum mixture $(39.11 \mathrm{~N})$. In BCRP samples, hardness values after $48 \mathrm{~h}$ were high in bread samples with $2 \mathrm{~g}$ white egg, xanthan \& guar gum mixture, and $3 \mathrm{~g}$ whey protein $(38.24,36.23$, and $35.70 \mathrm{~N}$, respectively). The lowest value of hardness at zero time was found in the FRP sample with $1.6 \mathrm{~g}$ xanthan \& guar gum mixture $(7.28 \mathrm{~N})$ as shown in Table 6 , and the BCRP sample with $7 \mathrm{~g}$ okra $(7.69 \mathrm{~N})$ as shown in Table (7).

In all tested formula samples, the hardness was increased by increasing storage period at room temperature. These results in agreement with Dłużewska et al., (2015) who reported that the hardness of gluten-free bread increased by increasing the storage period.

On the other side, hardness in flat bread was decreased by increasing of improvers levels. This observation may be due to the ability of tested improvers to absorb water and retaining moisture in bread samples as shown in Table 2. These results agree with (Bourne, 2002) who found that, the hardness or firmness values of cakes replacement with both flaxseed and okra gums decrease with the increase in replacement levels being more pronounced in cakes replaced with okra gum than flaxseed gum.

Adhesiveness, cohesiveness and Springiness of MRP, FRP and BCRP flat bread gluten free samples in zero time were increased by increasing the levels of improvers. While, the same parameters decreased progressively in storage at room temperature. The adhesiveness in different formula of gluten free bread scored the highest values with white egg improvers.

According to Cauvain (2004) Adhesiveness is the required force to overcome the tension between the food ingredients with another material that is in contact with the food (like the mouth, tongue, or even a metal surface).

The cohesiveness values in zero time were lowest in gluten free bread samples (MRP and FRP in Tables 5 and 6) with different levels of xanthan and guar gum mixture, while was the lowest in BCRP with white egg improver (Table 7). El-Sayed et al., (2014) mentioned that, cohesiveness in okra gum had higher values than cakes replaced with flaxseed gum and no significant differences with their controls.

Springiness was defined as the distance to which the sample recovered in height during the time that elapsed between the end of the first compression cycle and the start of the second compression cycle. From data in Tables (5-7), it could be seen that springiness in MRP, FRP and BCRP flat bread with $3 \mathrm{~g}$ 
Table 5: Texture profile analysis of MRP during storage period at room temperature

\begin{tabular}{|c|c|c|c|c|c|c|c|c|c|c|c|c|c|c|c|c|c|c|}
\hline \multirow{2}{*}{ 氡 } & \multicolumn{3}{|c|}{ Hardness (N) } & \multicolumn{3}{|c|}{ Adhesiveness (mj) } & \multicolumn{3}{|c|}{ Cohesiveness } & \multicolumn{3}{|c|}{ Springiness (mm) } & \multicolumn{3}{|c|}{ Gumminess (N) } & \multicolumn{3}{|c|}{ Chewiness (mj) } \\
\hline & $\begin{array}{c}\text { Zero } \\
\text { time }\end{array}$ & $24 h$ & $48 \mathrm{~h}$ & $\begin{array}{r}\text { Zero } \\
\text { time }\end{array}$ & $24 \mathrm{~h}$ & $48 \mathrm{~h}$ & $\begin{array}{c}\text { Zero } \\
\text { time }\end{array}$ & $24 \mathrm{~h}$ & $48 \mathrm{~h}$ & $\begin{array}{c}\text { Zero } \\
\text { time }\end{array}$ & $24 \mathrm{~h}$ & $48 \mathrm{~h}$ & $\begin{array}{c}\text { Zero } \\
\text { time }\end{array}$ & $24 \mathrm{~h}$ & $48 \mathrm{~h}$ & $\begin{array}{c}\text { Zero } \\
\text { time }\end{array}$ & $24 \mathrm{~h}$ & $48 \mathrm{~h}$ \\
\hline \multicolumn{19}{|c|}{ Okra } \\
\hline 3 & 21.62 & 23.45 & 44.85 & 4.80 & 3.90 & 2.70 & 2.10 & 1.41 & 0.80 & 7.96 & 6.24 & 5.99 & 13.17 & 17.26 & 46.89 & 197.80 & 267.90 & 306.40 \\
\hline 5 & 13.70 & 17.75 & 32.36 & 5.00 & 3.20 & 4.19 & 3.82 & 1.72 & 0.81 & 9.86 & 9.73 & 7.88 & 8.27 & 15.52 & 33.85 & 165.80 & 240.60 & 300.60 \\
\hline 7 & 8.59 & 11.47 & 28.78 & 10.00 & 7.00 & 5.10 & 4.08 & 2.64 & 1.24 & 10.00 & 9.75 & 8.68 & 14.83 & 11.40 & 24.77 & 131.60 & 215.80 & 256.40 \\
\hline \multicolumn{19}{|c|}{ Xanthan \& guar gum } \\
\hline 0.8 & 16.76 & 20.06 & 36.6 & 3.60 & 3.10 & 2.50 & 1.05 & 0.83 & 0.80 & 8.68 & 7.23 & 6.15 & 17.76 & 14.77 & 19.50 & 175.10 & 210.40 & 296.80 \\
\hline 1.2 & 11.95 & 17.34 & 23.12 & 4.40 & 4.20 & 2.50 & 1.53 & 1.37 & 1.05 & 9.28 & 8.16 & 7.19 & 12.13 & 13.19 & 18.21 & 124.40 & 148.20 & 266.90 \\
\hline 1.6 & 9.95 & 11.21 & 17.20 & 4.80 & 4.80 & 3.00 & 1.83 & 1.68 & 1.33 & 9.89 & 8.60 & 7.57 & 8.58 & 18.87 & 26.45 & 112.60 & 153.60 & 255.30 \\
\hline \multicolumn{19}{|c|}{ White egg } \\
\hline 2 & 30.42 & 41.28 & 44.36 & 4.80 & 4.20 & 2.30 & 1.14 & 0.83 & 0.83 & 9.17 & 8.14 & 5.77 & 20.40 & 28.93 & 35.47 & 184.10 & 289.30 & 253.40 \\
\hline 3 & 19.195 & 34.94 & 38.20 & 13.00 & 6.50 & 6.60 & 1.91 & 1.44 & 1.03 & 9.40 & 8.43 & 6.75 & 19.90 & 28.53 & 34.60 & 177.10 & 259.30 & 250.20 \\
\hline 4 & 16.98 & 22.39 & 26.46 & 15.70 & 12.00 & 8.50 & 2.55 & 2.02 & 1.09 & 10.58 & 9.17 & 7.06 & 19.58 & 25.50 & 29.08 & 110.50 & 203.06 & 248.30 \\
\hline \multicolumn{19}{|c|}{ Whey protein } \\
\hline 3 & 17.92 & 21.20 & 38.90 & 1.50 & 2.00 & 4.10 & 1.99 & 0.89 & 0.77 & 9.54 & 7.03 & 5.04 & 15.96 & 25.83 & 37.83 & 179.40 & 198.30 & 298.20 \\
\hline 5 & 13.25 & 18.84 & 22.86 & 2.10 & 3.70 & 5.19 & 2.21 & 0.89 & 0.88 & 9.55 & 7.62 & 5.32 & 10.40 & 21.81 & 29.40 & 141.60 & 155.80 & 218.30 \\
\hline 7 & 10.70 & 11.81 & 15.32 & 8.90 & 5.20 & 4.80 & 2.97 & 1.20 & 1.21 & 9.79 & 8.80 & 6.34 & 8.66 & 15.40 & 26.81 & 123.90 & 153.20 & 215.80 \\
\hline
\end{tabular}


Table 6: Texture profile analysis of FRP during storage period at room temperature

\begin{tabular}{|c|c|c|c|c|c|c|c|c|c|c|c|c|c|c|c|c|c|c|}
\hline \multirow{2}{*}{ 包 } & \multicolumn{3}{|c|}{ Hardness (N) } & \multicolumn{3}{|c|}{ Adhesiveness (mj) } & \multicolumn{3}{|c|}{ Cohesiveness } & \multicolumn{3}{|c|}{ Springiness (mm) } & \multicolumn{3}{|c|}{ Gumminess (N) } & \multicolumn{3}{|c|}{ Chewiness (mj) } \\
\hline & $\begin{array}{l}\text { Zero } \\
\text { time }\end{array}$ & $24 \mathrm{~h}$ & $48 \mathrm{~h}$ & $\begin{array}{c}\text { Zero } \\
\text { time }\end{array}$ & $24 \mathrm{~h}$ & $48 \mathrm{~h}$ & $\begin{array}{l}\text { Zero } \\
\text { time }\end{array}$ & $24 \mathrm{~h}$ & $48 \mathrm{~h}$ & $\begin{array}{l}\text { Zero } \\
\text { time }\end{array}$ & $24 \mathrm{~h}$ & $48 \mathrm{~h}$ & $\begin{array}{c}\text { Zero } \\
\text { time }\end{array}$ & $24 \mathrm{~h}$ & $48 \mathrm{~h}$ & $\begin{array}{l}\text { Zero } \\
\text { time }\end{array}$ & $24 \mathrm{~h}$ & $48 \mathrm{~h}$ \\
\hline \multicolumn{19}{|c|}{ Okra } \\
\hline 3 & 20.79 & 26.29 & 39.50 & 2.70 & 2.50 & 1.40 & 2.31 & 1.08 & 0.18 & 9.08 & 6.66 & 5.45 & 11.07 & 15.04 & 40.50 & 298.80 & 299.80 & 423.20 \\
\hline 5 & 12.93 & 22.34 & 32.02 & 3.30 & 2.90 & 2.30 & 3.17 & 1.32 & 1.07 & 9.16 & 7.12 & 6.86 & 10.64 & 12.59 & 12.40 & 290.80 & 223.90 & 322.30 \\
\hline 7 & 8.07 & 11.99 & 16.20 & 6.40 & 6.30 & 4.10 & 5.16 & 1.62 & 1.22 & 9.27 & 8.72 & 7.68 & 10.23 & 11.18 & 21.53 & 105.51 & 131.10 & 280.34 \\
\hline \multicolumn{19}{|c|}{ Xanthan \& guar gum } \\
\hline 0.8 & 18.43 & 23.2 & 39.11 & 2.60 & 1.70 & 1.60 & 1.07 & 1.02 & 0.67 & 9.27 & 7.83 & 6.01 & 13.07 & 13.17 & 19.67 & 185.50 & 273.60 & 293.70 \\
\hline 1.2 & 15.12 & 17.27 & 28.36 & 3.50 & 3.10 & 2.30 & 1.34 & 1.40 & 1.02 & 9.33 & 8.01 & 7.44 & 11.24 & 12.59 & 24.16 & 125.50 & 192.40 & 147.80 \\
\hline 1.6 & 7.28 & 9.52 & 16.56 & 5.50 & 4.70 & 3.70 & 1.46 & 1.67 & 1.15 & 9.38 & 8.20 & 7.69 & 9.12 & 10.05 & 14.87 & 108.70 & 123.80 & 140.10 \\
\hline \multicolumn{19}{|c|}{ White egg } \\
\hline 2 & 31.88 & 43.42 & 43.45 & 5.50 & 4.40 & 4.23 & 1.17 & 1.04 & 0.56 & 9.60 & 7.33 & 5.98 & 30.08 & 55.07 & 24.87 & 288.80 & 479.10 & 476.65 \\
\hline 3 & 28.5 & 34.01 & 37.21 & 9.50 & 7.32 & 7.00 & 2.03 & 1.20 & 0.84 & 9.87 & 8.03 & 6.70 & 22.65 & 24.91 & 23.30 & 222.20 & 249.90 & 354.87 \\
\hline 4 & 19.01 & 25.04 & 28.16 & 17.30 & 9.18 & 7.50 & 2.46 & 1.86 & 1.20 & 9.94 & 8.70 & 7.32 & 20.39 & 22.45 & 26.90 & 180.90 & 231.90 & 267.98 \\
\hline \multicolumn{19}{|c|}{ Whey protein } \\
\hline 3 & 18.87 & 29.82 & 37.80 & 4.10 & 2.30 & 1.70 & 1.73 & 1.10 & 0.46 & 9.26 & 6.66 & 5.67 & 11.58 & 14.27 & 19.27 & 158.20 & 183.80 & 314.50 \\
\hline 5 & 12.75 & 17.78 & 26.90 & 6.30 & 4.40 & 2.90 & 2.08 & 1.39 & 1.13 & 9.39 & 7.34 & 6.53 & 9.83 & 11.77 & 18.51 & 147.10 & 168.20 & 283.80 \\
\hline 7 & 8.21 & 12.32 & 19.86 & 7.50 & 6.30 & 3.40 & 2.51 & 1.49 & 1.69 & 9.88 & 8.15 & 6.90 & 9.53 & 8.51 & 12.77 & 139.00 & 110.50 & 228.20 \\
\hline
\end{tabular}

$\mathrm{FRP}=25 \mathrm{~g}$ flax seeds $+75 \mathrm{~g}$ rice $+50 \mathrm{~g}$ potato 
Table 7: Texture profile analysis of BCRP during storage period at room temperature

\begin{tabular}{|c|c|c|c|c|c|c|c|c|c|c|c|c|c|c|c|c|c|c|}
\hline \multirow{2}{*}{ 窇 } & \multicolumn{3}{|c|}{$\begin{array}{c}\text { Hardness } \\
(\mathrm{N})\end{array}$} & \multicolumn{3}{|c|}{$\begin{array}{c}\text { Adhesiveness } \\
\text { (mj) }\end{array}$} & \multicolumn{3}{|c|}{ Cohesiveness } & \multicolumn{3}{|c|}{$\begin{array}{l}\text { Springiness } \\
(\mathrm{mm})\end{array}$} & \multicolumn{3}{|c|}{$\begin{array}{c}\text { Gumminess } \\
\text { (N) }\end{array}$} & \multicolumn{3}{|c|}{$\begin{array}{c}\text { Chewiness } \\
\text { (mj) }\end{array}$} \\
\hline & $\begin{array}{r}\text { Zero } \\
\text { time }\end{array}$ & $24 \mathrm{~h}$ & $48 \mathrm{~h}$ & $\begin{array}{l}\text { Zero } \\
\text { time }\end{array}$ & $24 \mathrm{~h}$ & $48 \mathrm{~h}$ & $\begin{array}{r}\text { Zero } \\
\text { time }\end{array}$ & $24 \mathrm{~h}$ & $48 \mathrm{~h}$ & $\begin{array}{l}\text { Zero } \\
\text { time }\end{array}$ & $24 \mathrm{~h}$ & $48 \mathrm{~h}$ & $\begin{array}{l}\text { Zero } \\
\text { time }\end{array}$ & $24 \mathrm{~h}$ & $48 \mathrm{~h}$ & $\begin{array}{r}\text { Zero } \\
\text { time }\end{array}$ & $24 \mathrm{~h}$ & $48 \mathrm{~h}$ \\
\hline \multicolumn{19}{|c|}{ Okra } \\
\hline 3 & 16.38 & 12.33 & 17.65 & 3.40 & 3.22 & 1.45 & 1.91 & 1.02 & 1.63 & 8.16 & 6.58 & 5.68 & 11.74 & 14.24 & 43.14 & 194.30 & 267.45 & 322.85 \\
\hline 5 & 9.55 & 9.705 & 13.43 & 7.65 & 3.70 & 2.21 & 2.50 & 1.09 & 1.97 & 8.89 & 7.43 & 6.70 & 9.84 & 10.29 & 32.18 & 127.21 & 192.40 & 278.90 \\
\hline 7 & 7.69 & 8.93 & 11.76 & 9.53 & 4.90 & 2.30 & 3.27 & 1.40 & 2.24 & 9.06 & 8.88 & 7.90 & 6.34 & 9.80 & 27.57 & 151.50 & 191.56 & 241.64 \\
\hline \multicolumn{19}{|c|}{ Xanthan \& guar gum } \\
\hline 0.8 & 11.86 & 17.39 & 36.23 & 2.40 & 2.00 & 1.20 & 1.03 & 1.04 & 0.93 & 8.76 & 7.46 & 6.61 & 15.87 & 16.67 & 19.99 & 162.50 & 178.10 & 296.10 \\
\hline 1.2 & 8.64 & 12.22 & 21.39 & 4.50 & 2.80 & 1.80 & 1.08 & 1.42 & 1.04 & 9.14 & 8.03 & 7.79 & 13.46 & 15.80 & 18.85 & 123.00 & 174.00 & 184.40 \\
\hline 1.6 & 8.55 & 10.68 & 15.73 & 5.40 & 4.50 & 3.20 & 2.13 & 1.56 & 1.32 & 10.20 & 9.44 & 8.54 & 8.27 & 12.24 & 13.85 & 112.21 & 142.60 & 135.60 \\
\hline \multicolumn{19}{|c|}{ White egg } \\
\hline 2 & 29.24 & 36.86 & 38.24 & 4.30 & 2.40 & 1.20 & 1.02 & 1.04 & 0.79 & 8.71 & 7.90 & 5.16 & 20.70 & 32.81 & 35.16 & 163.00 & 263.50 & 356.89 \\
\hline 3 & 18.37 & 22.65 & 33.14 & 6.20 & 5.50 & 3.32 & 1.22 & 1.80 & 0.80 & 9.44 & 7.94 & 6.17 & 18.71 & 24.89 & 25.13 & 129.10 & 247.30 & 345.76 \\
\hline 4 & 15.93 & 16.21 & 21.50 & 10.70 & 9.10 & 5.70 & 1.87 & 1.99 & 1.04 & 9.52 & 8.03 & 6.21 & 11.46 & 17.57 & 21.04 & 109.50 & 173.90 & 255.30 \\
\hline \multicolumn{19}{|c|}{ Whey protein } \\
\hline 3 & 17.9 & 25.17 & 35.70 & 4.90 & 2.21 & 1.22 & 1.70 & 1.15 & 1.18 & 9.63 & 8.04 & 6.22 & 19.29 & 19.40 & 19.40 & 189.70 & 203.00 & 290.13 \\
\hline 5 & 11.2 & 13.02 & 19.50 & 5.70 & 3.30 & 2.65 & 1.72 & 1.25 & 1.59 & 10.16 & 8.82 & 7.18 & 11.14 & 11.51 & 15.20 & 164.00 & 199.00 & 233.18 \\
\hline 7 & 9.58 & 10.26 & 14.75 & 8.40 & 6.45 & 3.53 & 2.32 & 1.51 & 1.99 & 10.61 & 9.17 & 7.23 & 9.94 & 10.20 & 13.51 & 129.55 & 154.00 & 185.90 \\
\hline
\end{tabular}


okra, had the lowest values of springiness at zero time (7.96, 9.08 and 8.16, respectively). There was a decrease in springiness with storage time. El-Sayed et al., (2014) illustrated that, both levels of 75\% flaxseed gum and 50\% okra gum, exhibited an obvious lower values of springiness than the other levels of both gums and the controls.

Gumminess was calculated in product (by multiplying of hardness and cohesiveness), whereas chewiness, defined as the energy required to masticate solid food to a state of readiness for swallowing (Karaoglu and Kotancilar, 2009). Gumminess was increased by increasing improver levels and storage period in all tested samples (Tables 5-7).

Chewiness is the energy required to masticate bread into a state ready for swallowing; it is a product of hardness, cohesiveness and springiness. Chewiness parameters should be low to ensure consumer desirability. From data in Table (5), chewiness value ranged between $110.5 \mathrm{Nm}$ in MRP bread sample with $4 \mathrm{~g}$ white egg improver to $197.8 \mathrm{Nm}$ in bread sample with $3 \mathrm{~g}$ okra improver at zero time. On the other hand, chewiness value in FRP (able 6) ranged between $105.51 \mathrm{Nm}$ in FRP sample with $7 \mathrm{~g}$ okra to 298.80 Nm FRP sample with $3 \mathrm{~g}$ okra. The chewiness value in BCRP bread sample ranged between 109.5 Nm with $4 \mathrm{~g}$ white egg improver to $194.30 \mathrm{Nm}$ for BCRP bread sample with $3 \mathrm{~g}$ okra improver at zero time. Chewiness increased during storage period in all tested samples.

Results obtained from texture profile analysis (Tables 5-7) illustrate that hardness, gumminess and chewiness of all gluten-free flat bread samples were decreased by increasing all tested improvers levels and increased by storage time. On the contrary, adhesiveness, cohesiveness and springiness were increased by increasing of improvers levels and decreased by increasing storage period.

\subsection{Sensory evaluation of gluten-free flat bread samples}

Results of sensory evaluation of gluten-free flatbread are shown in Tables (8-10). From statistical analysis of sensory evaluation, it could be observed that there were significant differences $(P \leq 0.05)$ between all tested bread samples.

The general appearance was found the highest score when increasing levels of okra and xanthan \& guar gum improvers in gluten-free flatbread MRP, FRP, and BCRP (Table 8-10). Added okra and mixture of xanthan \& guar gum improvers in different levels enhanced all parameters of sensory glutenfree flatbread. Although, the gluten-free flatbread MRP, FRP, and BCRP with different levels of white egg and whey protein improvers recorded the lowest score in all sensory parameters but accepted by panelists.

There were significant differences in taste between gluten-free bread samples. Means recorded for taste in samples were between 19.33 in MRP with $7 \mathrm{~g}$ okra (Table 8) to 10.67 in FRP with 3 and $5 \mathrm{~g}$ whey protein (Table 9). There were no significant differences found in the separation of layers in gluten-free flatbread MRP, FRP, and BCRP samples with okra and xanthan \& guar gum mixture improvers.

There were slightly significant differences $(\mathrm{P} \leq 0.05)$ in crust color between all tested samples. Crust color of gluten-free bread samples had score ranged between 15 in both (MRP and FRP) with $7 \mathrm{~g}$ okra (Tables 8 and 9) and 11.67 in both (FRP and BCRP with $2 g$ white egg (Tables 9 and10) and $3 g$ whey protein in (Table 10). Crust color was accepted by panelists for all tested gluten-free bread samples.

Overall acceptability values ranged between 99.17 in the MRP bread sample with $7 \mathrm{~g}$ okra and 75.67 in the MRP bread sample with $3 \mathrm{~g}$ white egg improver (Table 8). While overall acceptability in FRP was 96.33 in the high levels of okra and 65.67 with $2 \mathrm{~g}$ white egg (Table 9). The BCRP samples scored highly overall acceptability 94.67 with $7 \mathrm{~g}$ okra and the lowest one 68.33 with $2 \mathrm{~g}$ white egg (Table 10). From the previous results, there is no raw material, additives, or ingredients that can completely substitute gluten, but the combination of raw materials, ingredients, and proper production technologies could promote the production of a gluten-free product of good quality.

The dairy proteins as caseins positively influence nutritional value (good sources of calcium and amino acids such as lysine, methionine, and tryptophan) and the quality of gluten-free products (Nunes et al., 2009 and KrUpa-KozaK et al., 2011). As well as, incorporation whey protein to gluten-free bread formulations improves texture and rise volume, taste and crust color of product. Crust darkening is based on the caramelization and Maillard reactions, due to the milk components including protein and lactose (De Mesa-Stonestreet et al., 2012). While,addition casein and egg white to dough based on rice flour improved handling and processing (Marti et al., 2014). The addition of proteins generally causes a rise in bread hardness and in enthalpy of retrograded amylopectin, during bread storage. 
Table 8: Sensory evaluation of MRP gluten-free flat bread with different levels of improvers

\begin{tabular}{|c|c|c|c|c|c|c|c|c|}
\hline $\begin{array}{c}\text { Improver } \\
\text { g/150g formula }\end{array}$ & $\begin{array}{c}\text { General } \\
\text { Appearance } \\
(\mathbf{2 0})\end{array}$ & $\begin{array}{c}\text { Crust Color } \\
\text { ( 15) }\end{array}$ & $\begin{array}{l}\text { Taste } \\
(20)\end{array}$ & $\begin{array}{l}\text { Odor } \\
(10)\end{array}$ & $\begin{array}{c}\text { Layers } \\
\text { Separation } \\
(15)\end{array}$ & $\begin{array}{l}\text { Texture } \\
\text { (10) }\end{array}$ & $\begin{array}{l}\text { Roundness } \\
\text { ( } 10)\end{array}$ & $\begin{array}{c}\text { Overall } \\
\text { acceptability } \\
(100)\end{array}$ \\
\hline \multicolumn{9}{|c|}{ Okra } \\
\hline 3 & $18.00^{\text {cdef }}$ & $13.67^{\mathrm{ab}}$ & $17.00^{\mathrm{abcd}}$ & $8.33^{\mathrm{abc}}$ & $13.00^{\mathrm{ab}}$ & $8.33^{\mathrm{abc}}$ & $8.33^{\mathrm{cd}}$ & $86.67^{\text {def }}$ \\
\hline 5 & $19.83^{\mathrm{ab}}$ & $14.83^{\mathrm{a}}$ & $18.67^{\mathrm{ab}}$ & $9.67^{\mathrm{a}}$ & $15.00^{\mathrm{a}}$ & $10.00^{\mathrm{a}}$ & $10.00^{\mathrm{a}}$ & $98.00^{\mathrm{ab}}$ \\
\hline 7 & $20.00^{\mathrm{a}}$ & $15.00^{\mathrm{a}}$ & $19.33^{\mathrm{a}}$ & $10.00^{\mathrm{a}}$ & $15.00^{\mathrm{a}}$ & $9.83^{\mathrm{a}}$ & $10.00^{\mathrm{a}}$ & $99.17^{\mathrm{a}}$ \\
\hline \multicolumn{9}{|c|}{ Xanthan \& guar gum } \\
\hline 0.8 & $18.00^{\text {cdef }}$ & $14.00^{\mathrm{ab}}$ & $17.67^{\mathrm{abc}}$ & $8.33^{\mathrm{abc}}$ & $15.00^{\mathrm{a}}$ & $8.33^{\mathrm{abc}}$ & $9.33^{\mathrm{abc}}$ & $90.67^{\mathrm{bcd}}$ \\
\hline 1.2 & $19.33^{\mathrm{abc}}$ & $14.00^{\mathrm{ab}}$ & $18.33^{\mathrm{abc}}$ & $8.67^{\mathrm{abc}}$ & $14.33^{\mathrm{a}}$ & $9.00^{\mathrm{ab}}$ & $8.67^{\mathrm{bc}}$ & $92.33^{\mathrm{abcd}}$ \\
\hline 1.6 & $19.67^{\mathrm{ab}}$ & $14.67^{\mathrm{ab}}$ & $18.67^{\mathrm{ab}}$ & $9.00^{\mathrm{ab}}$ & $15.00^{\mathrm{a}}$ & $9.67^{\mathrm{ab}}$ & $9.67^{\mathrm{ab}}$ & $96.33^{\mathrm{abc}}$ \\
\hline \multicolumn{9}{|c|}{ White egg } \\
\hline 2 & $16.67 \mathrm{f}$ & $12.67^{\mathrm{b}}$ & $16.33^{\text {bcde }}$ & $7.00^{\mathrm{c}}$ & $10.33^{\mathrm{bc}}$ & $7.00^{\mathrm{cd}}$ & $7.00^{\mathrm{e}}$ & $77.00^{\mathrm{g}}$ \\
\hline 3 & $17.33^{\text {def }}$ & $14.00^{\mathrm{ab}}$ & $14.67^{\mathrm{de}}$ & $7.67^{\mathrm{bc}}$ & $9.33^{\mathrm{c}}$ & $6.33^{\mathrm{d}}$ & $6.33^{\mathrm{e}}$ & $75.67^{\mathrm{g}}$ \\
\hline 4 & $17.67^{\mathrm{def}}$ & $12.67^{b}$ & $14.00^{\mathrm{e}}$ & $8.33^{\mathrm{abc}}$ & $13.00^{\mathrm{ab}}$ & $8.33^{\mathrm{abc}}$ & $7.33^{\mathrm{de}}$ & $81.33^{\mathrm{fg}}$ \\
\hline \multicolumn{9}{|c|}{ Whey protein } \\
\hline 3 & $17.00^{\mathrm{ef}}$ & $14.00^{\mathrm{ab}}$ & $15.67^{\text {cde }}$ & $7.00^{\mathrm{c}}$ & $12.67^{\mathrm{ab}}$ & $8.00^{\mathrm{bc}}$ & $8.33^{\mathrm{cd}}$ & $82.67^{\mathrm{efg}}$ \\
\hline 5 & $18.33^{\text {bcde }}$ & $13.67^{\mathrm{ab}}$ & $17.33^{\mathrm{abcd}}$ & $8.67^{\mathrm{abc}}$ & $14.00^{\mathrm{a}}$ & $9.00^{\mathrm{ab}}$ & $8.33^{\mathrm{cd}}$ & $89.33^{\text {cde }}$ \\
\hline 7 & $18.67^{\mathrm{abcd}}$ & $14.00^{\mathrm{ab}}$ & $16.00^{\text {bcde }}$ & $9.33^{\mathrm{ab}}$ & $12.67^{\mathrm{ab}}$ & $9.33^{\mathrm{ab}}$ & $9.17^{\mathrm{abc}}$ & $89.17^{\text {cde }}$ \\
\hline
\end{tabular}

In a column, means having the same superscript letters are not significantly different at $5 \%$ level.

$\mathrm{MRP}=25 \mathrm{~g}$ millet $+75 \mathrm{~g}$ rice $+50 \mathrm{~g}$ potato 
Table 9: Sensory evaluation of FRP gluten-free flat bread with different levels of improvers

\begin{tabular}{|c|c|c|c|c|c|c|c|c|}
\hline $\begin{array}{l}\text { Improver, } \\
\text { g/150g formula }\end{array}$ & $\begin{array}{c}\text { General } \\
\text { Appearance } \\
(\mathbf{2 0})\end{array}$ & $\begin{array}{c}\text { Crust Color } \\
\text { (15) }\end{array}$ & $\begin{array}{l}\text { Taste } \\
(20)\end{array}$ & $\begin{array}{l}\text { Odor } \\
\text { (1) }\end{array}$ & $\begin{array}{c}\text { Layers } \\
\text { Separation } \\
(15)\end{array}$ & $\begin{array}{l}\text { Texture } \\
\text { (10) }\end{array}$ & $\begin{array}{c}\text { Roundness } \\
\text { (10) }\end{array}$ & $\begin{array}{c}\text { Overall } \\
\text { acceptability } \\
(\mathbf{1 0 0})\end{array}$ \\
\hline \multicolumn{9}{|c|}{ Okra } \\
\hline 3 & $18.00^{\mathrm{abc}}$ & $13.00^{\mathrm{abc}}$ & $18.00^{\mathrm{a}}$ & $8.00^{\text {bc }}$ & $13.17^{\mathrm{a}}$ & $8.33^{\mathrm{abc}}$ & $8.00^{\mathrm{ab}}$ & $86.50^{\mathrm{bc}}$ \\
\hline 5 & $19.33^{\mathrm{ab}}$ & $14.33^{\mathrm{ab}}$ & $16.00^{\mathrm{abc}}$ & $8.33^{\mathrm{ab}}$ & $15.00^{\mathrm{a}}$ & $900^{\mathrm{ab}}$ & $8.50^{\mathrm{ab}}$ & $90.50^{\mathrm{ab}}$ \\
\hline 7 & $19.67^{\mathrm{a}}$ & $15.00^{\mathrm{a}}$ & $17.67^{\mathrm{a}}$ & $9.67^{\mathrm{a}}$ & $14.67^{\mathrm{a}}$ & $9.67^{\mathrm{a}}$ & $10.00^{\mathrm{a}}$ & $96.33^{\mathrm{a}}$ \\
\hline \multicolumn{9}{|c|}{ Xanthan \& guar gum } \\
\hline 0.8 & $16.00^{\text {de }}$ & $13.00^{\mathrm{abc}}$ & $13.33^{b c d}$ & $6.33^{\text {cde }}$ & $13.33^{\mathrm{a}}$ & $9.33^{\mathrm{ab}}$ & $7.67^{\mathrm{ab}}$ & $79.00^{\mathrm{cd}}$ \\
\hline 1.2 & $18.00^{\mathrm{abc}}$ & $13.33^{\mathrm{abc}}$ & $13.00^{\mathrm{cd}}$ & $7.33^{\mathrm{bcd}}$ & $15.00^{\mathrm{a}}$ & $9.00^{\mathrm{ab}}$ & $10.00^{\mathrm{a}}$ & $85.67^{\mathrm{bc}}$ \\
\hline 1.6 & $19.33^{\mathrm{ab}}$ & $14.33^{\mathrm{ab}}$ & $15.67^{\mathrm{abc}}$ & $7.00^{\text {bcde }}$ & $15.00^{\mathrm{a}}$ & $9.67^{\mathrm{a}}$ & $10.00^{\mathrm{a}}$ & $91.00^{\mathrm{ab}}$ \\
\hline \multicolumn{9}{|c|}{ White egg } \\
\hline 2 & $15.67^{\mathrm{e}}$ & $11.67^{\mathrm{c}}$ & $11.67^{\mathrm{cd}}$ & $5.33^{e}$ & $8.33^{\mathrm{cd}}$ & $6.33^{c}$ & $6.67^{b}$ & $65.67^{\mathrm{e}}$ \\
\hline 3 & $16.67^{\text {cde }}$ & $13.33^{\mathrm{abc}}$ & $12.33^{\mathrm{cd}}$ & $6.67^{\text {bcde }}$ & $10.33^{b c}$ & $8.00^{\mathrm{abc}}$ & $7.00^{\mathrm{b}}$ & $74.33^{\text {de }}$ \\
\hline 4 & $16.67^{\text {cde }}$ & $12.67^{\mathrm{bc}}$ & $11.67^{\mathrm{cd}}$ & $6.00^{\text {de }}$ & $11.00^{\mathrm{b}}$ & $8.33^{\mathrm{abc}}$ & $8.00^{\mathrm{ab}}$ & $74.33^{\mathrm{de}}$ \\
\hline \multicolumn{9}{|c|}{ Whey protein } \\
\hline 3 & $16.00^{\mathrm{de}}$ & $12.67^{\mathrm{bc}}$ & $10.67^{\mathrm{d}}$ & $7.33^{\mathrm{bcd}}$ & $7.67^{d}$ & $7.00^{\mathrm{bc}}$ & $8.00^{\mathrm{ab}}$ & $69.33^{\mathrm{e}}$ \\
\hline 5 & $16.33^{\text {cde }}$ & $12.67^{\mathrm{bc}}$ & $10.67^{\mathrm{d}}$ & $7.33^{\mathrm{bcd}}$ & $7.67^{\mathrm{d}}$ & $7.67^{\mathrm{abc}}$ & $8.00^{\mathrm{ab}}$ & $70.33^{\mathrm{de}}$ \\
\hline 7 & $17.67^{\mathrm{bcd}}$ & $12.33^{\mathrm{bc}}$ & $17.33^{\mathrm{abc}}$ & $6.33^{\text {cde }}$ & $9.67^{\mathrm{bcd}}$ & $8.00^{\mathrm{abc}}$ & $7.67^{\mathrm{ab}}$ & $79.00^{\mathrm{cd}}$ \\
\hline
\end{tabular}

In a column, means having the same superscript letters are not significantly different at 5\% level.

$\mathrm{FRP}=25 \mathrm{~g}$ flax seeds $+75 \mathrm{~g}$ rice $+50 \mathrm{~g}$ potato 
Table 10: Sensory evaluation of BCRP gluten-free flat bread with different levels of improvers

\begin{tabular}{|c|c|c|c|c|c|c|c|c|}
\hline $\begin{array}{c}\text { Improver } \\
\text { g/150g formula }\end{array}$ & $\begin{array}{c}\text { General } \\
\text { Appearance } \\
(\mathbf{2 0}) \\
\end{array}$ & $\begin{array}{c}\text { Crust Color } \\
\text { (15) }\end{array}$ & $\begin{array}{l}\text { Taste } \\
(20)\end{array}$ & $\begin{array}{l}\text { Odor } \\
(10)\end{array}$ & $\begin{array}{c}\text { Layers } \\
\text { Separation } \\
(15) \\
\end{array}$ & $\begin{array}{l}\text { Texture } \\
\text { (10) }\end{array}$ & $\begin{array}{l}\text { Roundness } \\
\text { (10) }\end{array}$ & $\begin{array}{c}\text { Overall } \\
\text { acceptability (100) }\end{array}$ \\
\hline \multicolumn{9}{|c|}{ Okra } \\
\hline 3 & $17.33^{\mathrm{cd}}$ & $12.67^{\mathrm{abc}}$ & $14.67^{\mathrm{bc}}$ & $8.00^{\mathrm{cd}}$ & $13.67^{\mathrm{a}}$ & $9.00^{\mathrm{a}}$ & $8.33^{\mathrm{ab}}$ & $83.67^{\mathrm{c}}$ \\
\hline 5 & $19.33^{\mathrm{a}}$ & $14.33^{\mathrm{ab}}$ & $17.67^{\mathrm{a}}$ & $9.33^{\mathrm{ab}}$ & $14.67^{\mathrm{a}}$ & $9.67^{\mathrm{a}}$ & $8.67^{\mathrm{ab}}$ & $93.67^{\mathrm{ab}}$ \\
\hline 7 & $19.00^{\mathrm{ab}}$ & $14.33^{\mathrm{ab}}$ & $17.00^{\mathrm{ab}}$ & $10.00^{\mathrm{a}}$ & $15.00^{\mathrm{a}}$ & $9.67^{\mathrm{a}}$ & $9.67^{\mathrm{a}}$ & $94.67^{\mathrm{a}}$ \\
\hline \multicolumn{9}{|c|}{ Xanthan \& guar gum } \\
\hline 0.8 & $18.00^{\mathrm{abc}}$ & $13.00^{\mathrm{abc}}$ & $14.00^{\mathrm{bc}}$ & $6.00^{\mathrm{e}}$ & $13.00^{\mathrm{ab}}$ & $9.00^{\mathrm{a}}$ & $9.00^{\mathrm{ab}}$ & $82.00^{c}$ \\
\hline 1.2 & $19.00^{\mathrm{ab}}$ & $14.33^{\mathrm{ab}}$ & $14.33^{\mathrm{bc}}$ & $7.00^{\mathrm{de}}$ & $13.00^{\mathrm{ab}}$ & $9.33^{\mathrm{a}}$ & $9.00^{\mathrm{ab}}$ & $86.00^{c}$ \\
\hline 1.6 & $19.33^{\mathrm{a}}$ & $14.33^{\mathrm{ab}}$ & $14.00^{\mathrm{bc}}$ & $7.67^{\mathrm{cd}}$ & $14.00^{\mathrm{a}}$ & $9.33^{\mathrm{a}}$ & $9.00^{\mathrm{ab}}$ & $87.67^{\mathrm{bc}}$ \\
\hline \multicolumn{9}{|c|}{ White egg } \\
\hline 2 & $16.33^{\mathrm{d}}$ & $13.33^{\mathrm{abc}}$ & $11.67^{\mathrm{c}}$ & $6.00^{\mathrm{e}}$ & $9.67^{d}$ & $7.33^{b}$ & $6.00^{c}$ & $68.33^{d}$ \\
\hline 3 & $16.33^{\mathrm{d}}$ & $11.67^{\mathrm{c}}$ & $13.00^{c}$ & $6.33^{\mathrm{e}}$ & $11.67^{\mathrm{bc}}$ & $8.00^{\mathrm{a}}$ & $8.00^{\mathrm{b}}$ & $75.00^{\mathrm{d}}$ \\
\hline 4 & $16.67^{\mathrm{cd}}$ & $12.00^{\mathrm{bc}}$ & $11.67^{\mathrm{c}}$ & $6.00^{\mathrm{e}}$ & $11.00^{\mathrm{cd}}$ & $8.33^{\mathrm{a}}$ & $8.33^{\mathrm{ab}}$ & $74.00^{\mathrm{d}}$ \\
\hline \multicolumn{9}{|c|}{ Whey protein } \\
\hline 3 & $17.67^{\mathrm{bcd}}$ & $11.67^{\mathrm{c}}$ & $14.67^{\mathrm{bc}}$ & $8.00^{\mathrm{cd}}$ & $14.33^{\mathrm{a}}$ & $8.33^{\mathrm{a}}$ & $8.33^{\mathrm{ab}}$ & $83.00^{c}$ \\
\hline 5 & $18.00^{\mathrm{abc}}$ & $12.33^{\mathrm{abc}}$ & $14.00^{\mathrm{bc}}$ & $7.67^{\mathrm{cd}}$ & $13.33^{\mathrm{ab}}$ & $9.00^{\mathrm{a}}$ & $8.00^{\mathrm{b}}$ & $82.33^{\mathrm{c}}$ \\
\hline 7 & $19.00^{\mathrm{ab}}$ & $14.67^{\mathrm{a}}$ & $14.33^{\mathrm{bc}}$ & $8.33^{\mathrm{bc}}$ & $13.67^{\mathrm{a}}$ & $9.33^{\mathrm{a}}$ & $8.33^{\mathrm{ab}}$ & $87.67^{\mathrm{bc}}$ \\
\hline
\end{tabular}

In a column, means having the same superscript letters are not significantly different at $5 \%$ level.

$\mathrm{BCRP}=20 \mathrm{~g}$ rice bran $+30 \mathrm{~g}$ corn $+50 \mathrm{~g}$ rice $+50 \mathrm{~g}$ potato 
Loaf volume rose up to a certain xanthan gum supplementation level, but further increase in polymer concentration resulted in volume decrease (Mastromatteoetal., 2012). It seems that with xanthan gum addition at high concentrations, dough exhibits too high resistance and consistency, which cause a limited gas cell expansion during proofing (Lazaridou etal., 2007). Similarly, Haque and Morris (1994) observed no influence of xanthan incorporation into a rice flour bread, whereas Schober et al., (2005) found a decrease in loaf volume of gluten-free breads from sorghum with increasing xanthan gum levels.

Table (9) showed that there were significant differences $(\mathrm{P} \leq 0.05)$ between all gluten-free bread samples in odor. Odor values ranged between 10 in MRP with $7 \mathrm{~g}$ okra (Table 8) and 5.33 in FRP with $2 \mathrm{~g}$ white egg (Table 9).

It could be seen that there were significant differences $(\mathrm{P} \leq 0.05)$ between all gluten-free flatbread samples in the separation of layers. The mean score of samples were improved by all levels of okra and $1.6 \mathrm{~g}$ mixture of xanthan \& guar gum. They recorded the highest score value in the separation of layers; it was 15 in MRP with the levels of okra and xanthan \& guar gum (Table 8). The means score of layer separation was decreased to reach 7.67 for FRP with 3 and $5 \mathrm{~g}$ whey protein (Table 9).

There were slightly significant differences between all samples in texture. The texture in all samples was accepted by panelists. From Tables $8-10$ it could be observed that there were significant differences $(\mathrm{P} \leq 0.05)$ between all gluten-free samples in roundness. It is evident from the results that the MRP bread sample with 5 and $7 \mathrm{~g}$ okra (Table 8) and FRP with $7 \mathrm{~g}$ okra and 1.2 and $1.6 \mathrm{~g}$ xanthan $\&$ guar gum (Table 9) had the highest score. From the results in Tables 8-10, overall acceptability values indicated that the MRP bread sample with $7 \mathrm{~g}$ okra had the highest scores (99.17).

\section{Conclusion}

The results showed that using a specific mixture such as FRP, MRP, and BCRP along with different types of improvers resulted in the production of gluten-free flatbreads containing high levels of nutrients. Among the improvers used in this study, Okra at levels 3, 5 and $7 \mathrm{~g}$ improved the freshness, texture profile analysis and sensory evaluation of the gluten-free flatbread compared to other improvers used.

\section{References}

A.O.A.C., 2010. Official Methods of Analysis of Association of Official Analytical Chemists. $18^{\text {th }}$ Edition, Washington, DC.

Arendt, E.K. and F. Dal Bello, 2008. Functional cereal products for those with gluten intolerance. In Technology of Functional Cereal Products; Wood head Publishing: Cambridge, UK, pp. 446-475.

Arendt, E.K., Morrissey, A., Moore, M.M. and F. Dal Bello, 2008. Gluten-free breads. In Gluten-Free Cereal Products and Beverages; Elsevier: Cham, Switzerland, 289-VII.

Armitage, P., G. Berry, and J.N.S. Matthews, 1987. Comparison of several groups. Statistical methods in medical research, $4^{\text {th }}$ ed., Blackwell Science, New York 186, 213.

Bárcenas, M.E., C. Benedito, and C.M. Rosell, 2004. Use of hydrocolloids as bread improvers in interrupted baking process with frozen storage. Food Hydrocolloids, 18(5): 769-774.

Belorio, M., and M. Gómez, 2020. Effect of Hydration on Gluten-Free Breads Made with Hydroxypropyl Methylcellulose in Comparison with Psyllium and Xanthan Gum. Foods, 9 (11): 1548

Benkadri, S., A. Salvador, T. Sanz, and M.N. Zidoune, 2021. Article optimization of xanthan and locust bean gum in a gluten-free Infant biscuit based on rice-chickpea flour using response surface methodology. Foods, 10 1): 12. https://www.mdpi.com/journal/foods

Bourne, M., 2002. Food texture and viscosity: concept and measurement. $2^{\text {nd }}$ ed. New York, Academic Press, 416.

Bourne, M., A. Neely, J. Mills, and K. Platts, 2003. Implementing performance measurement systems: a literature review. International Journal of Business Performance Management, 5 (1): 1-24.

Cauvain, S. P. 2004. Improving the texture of bread. TextureinFood, 2: 432-450.

De Mesa-Stonestreet, N.J., S. Alavi, and J. Gwirtz, 2012. Extrusion-enzyme liquefaction as a method for producing sorghum protein concentrates. Journal of Food Engineering, 108 (2): 365-375. 
Deogade, U.M., V.N. Deshmukh, and D.M. Sakarkar, 2012. Natural gums and mucilage's in NDDS: applications and recent approaches. International Journal of PharmTech Research, 4(2): 799-814.

Dłużewska, E., K. Marciniak-Lukasiak, and N. Kurek, 2015. Effect of trans glutaminase additive on the quality of gluten-free bread. CyTA-Journal of Food, 13(1): 80-86.

Duodu, K.G. and J.R.N. Taylor, 2012. The quality of breads made with non-wheat flours. In Bread making; Wood head Publishing: Cambridge, UK, 754-782.

El-Sayed, M.A., O.E. Shaltout, E.A. El-Difrawy, H.M. Osman, and A.E. Naga, 2014. Production and Evaluation of Low Fat Cake Containing Flaxseed and Okra Gums as a Fat Replacer. Alexandria Journal of Food Science and Technology, 367(3216): 1-8.

Gray, J.A. and J.N. BeMiller, 2003. Bread staling: Molecular basis and control. Comprehensive Reviews in Food Science and Food Safety, 2: 1-21.

Hager, A.S., and E.K. Arendt, 2013. Influence of hydroxyl propyl methyl cellulose HPMC), xanthan gum and their combination on loaf specific volume, crumb hardness and crumb grain characteristics of gluten-free breads based on rice, maize, teff and buckwheat. Food Hydrocolloids, 32(1): 195-203.

Haque, A. and E.R. Morris, 1994. Combined use of ispaghula and HPMC to replace or augment gluten in bread making. Food Research International, 27(4): 379-393.

Karaoğlu, M.M. and H.G. Kotancilar, 2009. Quality and textural behavior of par-baked and rebaked cake during prolonged storage. International Journal of Food Science and Technology, 44(1): 9399.

Kitterman, J.S. and G.L. Rubenthaler, 1971. Assessing quality of early generation wheat selections with micro AWRC test. Cereal Science Today, 16 (9): 313-316.

Kohajdova, Z. and J. Karovicova, 2009. Application of hydrocolloids as baking ' improvers. Chemical Papers, 63(1):26-38.

KrUpa-KozaK, U., M. Wronkowska, and M. Soral-Śmietana, 2011. Effect of buckwheat flour on microelements and proteins contents in gluten-free bread. Czech Journal of Food Sciences, 29(2): 103-108.

Kulp, K. and J.G.Jr. Ponte, 1981. Staling of white pan bread: fundamental causes. CRC Critical Reviews in Food Scienceand Nutrition, 15(1):1-48.

Lazaridou, A., D. Duta, M. Papageorgiou, N. Belc, and C.G. Biliaderis, 2007. Effects of hydrocolloids on dough rheology and bread quality parameters in gluten-free formulations. Journal of Food Engineering, 79(3): 1033-1047.

Mandala, I.G. and K. Sotirakoglou, 2005. Effect of frozen storage and microwave reheating on some physical attributes of fresh bread containing hydrocolloids. Food Hydrocolloids, 19:709-719.

Marti, A., A. Barbiroli, M. Marengo, L. Fongaro, S. Iametti, and M.A. Pagani, 2014. Structuring and texturing gluten-free pasta: egg albumen or whey proteins? European Food Research and Technology, 238 (2): 217-224.

Mastromatteo, M., A. Danza, M. Guida, and M.A. Del Nobile, 2012. Formulation optimisation of vegetable flour-loaded functional bread Part I: screening of vegetable flours and structuring agents. International Journal of Food Science and Technology, 47(6): 1313-1320.

Matos, M.E. and C.M. Rosell, 2015. Understanding gluten-free dough for reaching breads with physical quality and nutritional balance. J. Sci. Food Agric., 95: 653-661.

Nunes, M.H.B., M.M. Moore, L.A. Ryan, and E.K. Arendt, 2009. Impact of emulsifiers on the quality and rheological properties of gluten-free breads and batters. European Food Research and Technology, 228(4): 633-642.

Onyango, C., C. Mutungi, G. Unbehend, and M.G. Lindhauer, 2011. Modification of gluten-free sorghum batter and bread using maize, potato, cassava or rice starch. LWT-Food Science and Technology, 44(3): 681-686.

Piga, A., P. Catzeddu, S. Farris, T. Roggio, A. Sanguinetti, and E. Scano, 2005. Texture evolution of "Amaretti” cookies during storage. European Food Research and Technology, 221(3-4): 387-391.

Ren, Y., B.R. Linter, R. Linforth, and T.J. Foster, 2020. A comprehensive investigation of gluten free bread dough rheology, proving and baking performance and bread qualities by response surface design and principal component analysis. Food Funct., 11: 5333-5345.

Rosell, C.M., J.A. Rojas, and C.B. De Barber, 2001. Influence of hydrocolloids on dough rheology and bread quality. Food Hydrocolloids, 15 (1): 75-81. 
Schober, T.J., M. Messerschmidt, S.R. Bean, S.H. Park, and E.K. Arendt, 2005. Gluten-free bread from sorghum: quality differences among hybrids. Cereal Chemistry, 82 (4): 394-404.

Shalini, K.G. and A. Laxmi, 2007. Influence of additives on rheological characteristics of whole-wheat dough and quality of chapatti Indian Unleavened Flat Bread) Part I-Hydrocolloids. Food Hydrocolloids, 21:110-117.

Steel, R.G.D. and J.H. Torrie, 1980. Principles and procedures of statistics, a biometrical approach $2^{\text {nd }}$ Ed.. McGraw-Hill Kogakusha, Ltd.

Szczesniak, A.S., M.A. Brandt, and H.H. Friedman, 1963. Development of standard rating scales for mechanical parameters of texture and correlation between the objective and the sensory methods of texture evaluation. Journal of Food Science, 28 (4): 397-403.

Wang, K., L.U. Fei, Z. Li, L. Zhao, and C. Han, 2017. Recent developments in gluten-free bread baking approaches: A review, Food Science and Technology, Campinas, 37(1): 1-9.

Wu, K.L., W.C. Sung, and C.H. Yang, 2009. Characteristics of dough and bread as affected by the incorporation of sweet potato paste in the formulation. Journal of Marine Science Technology 17(1):13-22.

Zahran, M.M., K.B. Abdel-Aziz, A. Abdel-Raof, and E.M. Nahas, 2005. The effect of subacute doses of organophosphorus pesticide, Nuvacron, on the biochemical and cytogenetic parameters of mice and their embryos. Research Journal of Agriculture and Biological Sciences, 1(3): 277-283. 